\title{
Implikasi narrative therapy berbasis nilai-nilai bundo kanduang untuk meningkatkan kepuasan pernikahan pasangan usia dini
}

\author{
Yenni Elfira*), Neviyarni Suhaili, Marjohan Marjohan, Ifdil Ifdil, Afdal Afdal \\ Universitas Negeri Padang, Indonesia
}

\begin{tabular}{l} 
Article Info \\
\hline Article history: \\
Received Oct $03^{\text {rd }}, 2021$ \\
Revised Nov $20^{\text {th }}, 2021$ \\
Accepted Des $30^{\text {th }}, 2021$ \\
\hline
\end{tabular}

\section{Keyword:}

Narrative therapy

Nilai-nilai Bundo Kanduang

Kepuasan pernikahan

Pasangan usia dini

\begin{abstract}
Pernikahan pasangan di usia muda menjadi sebuah tred di zaman sekarang diberbagai daerah perdesaan yang rentang berakhir dengan perpisahan yang disebabkan oleh berbagai konflik dalam rumah tangga. Pasangan suami- isteri pernikahan usia dini rentan belum mampu untuk memenuhi serta mengetahui hak dan kewajiban, hal ini terjadi karena mental mereka yang masih memiliki sifat keegoisan yang tinggi sehingga menyebabkan pertengkaran, percecokkan, bentrokan antar suami isteri yang dapat mengakibatkan perceraian. Sehingga tingkat kepuasan pernikahan pasangan usia dini rata-rata tergolong rendah. Terapi naratif dapat berdampak positif pada kepuasan pernikahan, dalam terapi naratif orang dipandang sebagai ahli utama dalam kehidupan mereka, masalah dieksternalisasi dan efeknya diselesaikan dengan keterampilan, keyakinan, nilai, dan kemampuan mereka sendiri dengan menghayati nilai-nilai bundo kanduang.
\end{abstract}

(C) 2022 The Authors. Published by IICET.

This is an open access article under the CC BY-NC-SA license

(https://creativecommons.org/licenses/by-nc-sa/4.0)

\section{Corresponding Author:}

Yenni Elfira,

Universitas Negeri Padang

Email: yennielfira8@gmail.com

\section{Pendahuluan}

Setiap individu yang berniat untuk melangsungkan pernikahan tentunya berharap sekali seumur hidup, akan berbagi suka dan duka bersama, akan berusaha bersama-sama menjalin rumah tangga yang sakinah bahkan akan menghadapi bersama keadaan sulit sekalipun. Seperti halnya yang dikemukakan Karney \& Bradbury (2020), tidak ada orang yang menikah dengan niat bercerai. Konsep dasar suatu pernikahan berawal dari kesiapan dan kesanggupan setiap pasangan untuk mendirikan rumah tangga. Persoalannya sekarang perceraian sudah menjadi hal biasa dilakukan oleh beberapa orang, bahkan perceraian sudah menjadi sebuah gejala umum terjadi di masyarakat.

Perceraian rentan terjadi pada pasangan usia muda yaitu pasangan yang menikah ketika berusia dibawah 21 tahun, hal ini disebabkan dari sisi kesiapan baik mental, fisik, ekonomi dan kebutuhan lainnya ataupun kebanyakkan pasangan yang menikah muda kurang memiliki kesadaran dan tanggung jawab terhadap rumah tangga baik sebagai istri maupun suami (Wowor 2020). Kasus perceraian paling tinggipun 10 tahun terakhir ini yaitu pasangan yang melakukan pernikahan usia muda (Asak and Wilani 2019). Hal ini membuktikan bahwa masa remaja adalah masa topan badainya dan gejolaknya stress individu, dimana masa itu individu sering mengalami konflik dan susah dalam pengaturan suasana hari atau secara psikologisnya pergantian emosi yang terjadi berlangsung lebih sering (Santrock 2002).

Pernikahan yang berlangsung pada usia dini umumnya akan menimbulkan masalah baik secara fisiologis, psikologis maupun sosial ekonomi. Dampak dan resiko yang timbul akibat pernikahan dini 
pada umumnya lebih banyak dialami oleh perempuan. Diantaranya dari aspek kesehatan yaitu terjadinya infeksi pada kandungan, penyakit menular seksual, kanker mulut rahim, keguguran dan masalah kesehatan reproduksi lainnya, hal ini dikarenakan organ reproduksi perempuan belum siap menerima kehamilan sehingga dapat menimbulkan berbagai komplikasi. Perempuan muda yang sedang hamil, berdasarkan penelitian akan mengalami beberapa hal, seperti akan mengalami pendarahan, keguguran, dan persalinan yang lama atau sulit. Perempuan usia 15-19 tahun memiliki kemungkinan dua kali lebih besar meninggal saat melahirkan dibandingkan yang berusia 20-25 tahun, sedangkan usia di bawah 15 tahun kemungkinan meninggal bisa lima kali lebih besar dibanding yang berusia 20-25 tahun. Selain itu 54\% memiliki tingkat pengetahuan rendah, $70 \%$ berpenghasilan rendah, dan $66.7 \%$ memiliki sosial budaya yang negatif (Juliawati, Novita, and Yolandia 2021).

Permasalahan lain mengungkapkan bahwa kebanyakkan pernikahan pasangan usia dini kurang mampu untuk memenuhi kebutuhan rumah tangganya, kebutuhan rumah tangga dan keperluan anak ditanggung oleh orang tua (Mangande and Lahade 2021). Selain itu pasangan suami- isteri pernikahan usia dini ini belum mampu untuk dapat memenuhi serta mengetahui hak dan kewajiban, hal ini terjadi karena mental mereka yang masih memiliki sifat keegoisan yang tinggi sehingga menyebabkan pertengkaran, percecokkan, bentrokan antar suami isteri yang dapat mengakibatkan perceraian (Tampubolon 2021).

Data angka perceraian di Indonesia, secara umum Indonesia mengalami peningkatan perceraian dari tahun ke tahun, dapat dilihat dari data yang ditunjukkan pada gambar di bawah ini:
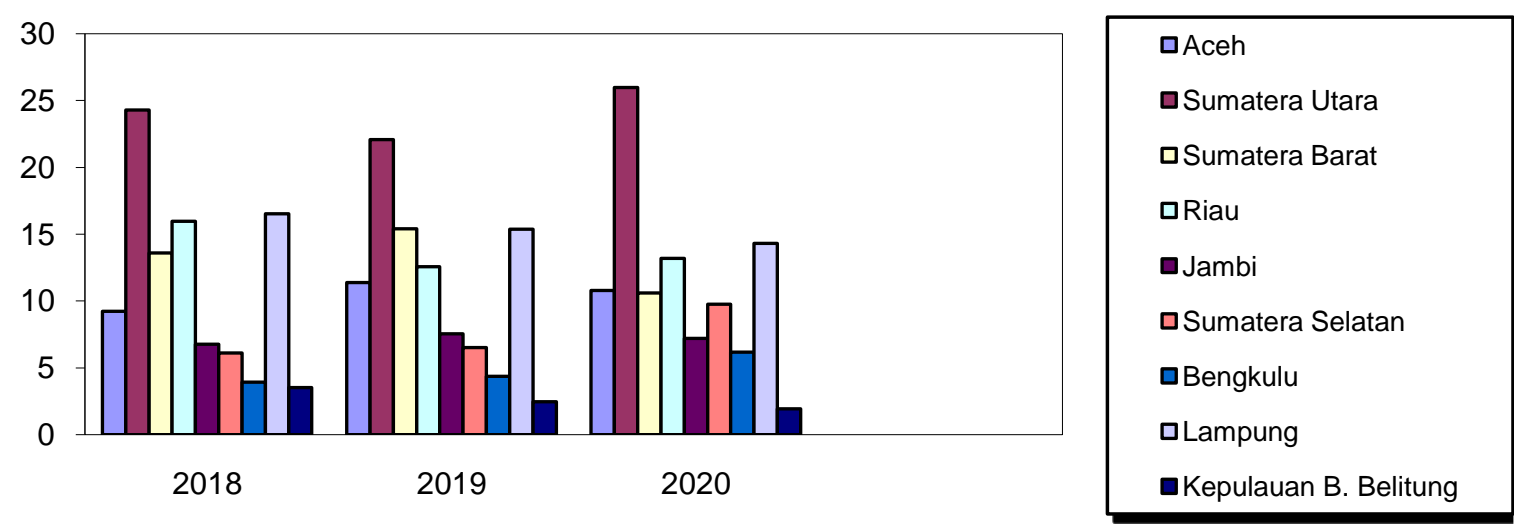

Gambar 1. Peceraian di 9 Provinsi Sumatera tahun 2018-2020

Sumber: BPS dan diolah oleh peneliti

Sumatera Barat merupakan provinsi di Indonesia yang beridentitas budaya tersendiri, dikenal dengan budaya Minangkabau. Populer dengan sistem kekerabatan matrilinial, kekerabatan matrilinial adalah garis keturunan dan pewarisan dari ibu, ini menjadi komponen penting dalam budaya minangkabau. Salah satunya nilai budaya bundo kandung dapat dijadikan salah satu model dalam pengembangan nilai-nilai karakter melalui pelayanan bimbingan dan konseling. Nilai-nilai budaya bundo kanduang banyak yang mengandung unsur pendidikan. Nilai-nilai ini dijadikan sebagai pedoman dalam bersikap, berpikir dan bertindak bagi masyarakat minangkabau. Adapun nilai-nilai budaya bundo kanduang di minangkabau yang mengandung unsur-unsur konseling diantaranya: (1) nilai keberanian, (2) kebenaran, (3) kejujuran, (4) kekonsistenan, (5) keoptimisan, (6) ketakwaan, (7) keterbukaan, (8) kecerdasan, (9) kekreatifan, (10) penyesuaian, (11) kemandirian dan, (12) nilai tanggungjawab. Nilai yang terkandung dalam budaya bundo kanduang ini selaras dengan nilai-nilai pendidikan karakter (Syaputra et al. 2019).

Berdasarkan paparan data pada gambar 1.1 di atas, terlihat masih tingginya angka perceraian di beberapa daerah provinsi di pulau Sumatera. Tentunya kondisi ini sangat menarik itu dicermati, karena perceraian bukan saja dilarang oleh semua ajaran agama, tetapi berdampak negatif terhadap pasangan yang bercerai, terlebih-lebih berdampak buruk pada psikologis anak-anak (Köppen, Kreyenfeld, and Trappe 2018). Dari hasil penelitian tersebut menggambarkan tingkat kepuasan pernikahan pasangan usia dini rata-rata tergolong rendah (Haryanto et al. 2021). Terapi naratif dapat berdampak positif pada kepuasan pernikahan, dalam terapi naratif orang dipandang sebagai ahli utama dalam kehidupan mereka, masalah dieksternalisasi dan efeknya diselesaikan dengan keterampilan, keyakinan, nilai, dan kemampuan mereka sendiri (Ghavibazou, Hosseinian, and Abdollahi 2020). Sehingga tujuan penulisan artikel ini adalah mendeskripsikan implikasi narrative therapy berbasis nilai-nilai bundo kanduang untuk meningkatkan kepuasan pernikahan pasangan usia dini. 


\section{Metode}

Penelitian menggunakan pendekatan studi literatur sistematik tentang berbagai literatur mengenai Implikasi Narrative Therapy Berbasis Nilai-Nilai Bundo Kanduang Untuk Meningkatkan Kepuasan Pernikahan Pasangan Usia Dini. Tinjauan kepustakaan ini merupakan studi objektif melalui ringkasan dan analisis terhadap literatur. Tujuan utama dari penggunaan pendekatan ini yaitu memberikan gambaran tentang pengaplikasi terapi naratif dan kepuasan pernikahan pasangan usia dini. Penulis mengumpulkan berbagai artikel yang kemudian dianalisi dengan metode deskriptif. Metode deskriptif yakni mendeskripsikan fakta-fakta dengan analisis atauupun penjelasan mengenai implikasi narrative therapy berbasis nilai-nilai bundo kanduang untuk meningkatkan kepuasan pernikahan pasangan usia dini.

\section{Hasil dan Pembahasan}

\section{Pernikahan Pasangan Usia Dini}

Secara umum, pernikahan yaitu jalinan serta ikatan batin seorang laki-laki dengan perempuan yang mempunyai jalinan suami istri dengan tujuan untuk membentuk sebuah keluarga bahagia yang bersumber dari Tuhan Yang Maha Esa yang dilakukan sebelum berumur 19 tahun (Jannah, Paluttur, and Syafar 2021) Defenisi pernikahan usia dini yakni institusi agung untuk mengikat dua insan lawan jenis yang masih remaja dalam satu ikatan keluarga (Jannah et al. 2021). Usia ideal menikah pada perempuan yaitu 21-25 tahun dan pada laki-laki 25-28 tahun karena di usia itu organ reproduksi perempuan secara psikologis sudah berkembang secara baik dan kuat serta siap melahirkan begitu pula pada laki-laki pada umur 25-28 akan siap untuk menopang kehidupan keluarganya. Pernikahan pada usia dini menimbulkan persoalaan hukum, melanggar undang-undang tentang pernikahan, perlindungan anak dan Hak Asasi Manusia (Dwinanda, Wijayanti, and Werdani 2017). Selain itu, pernikahan usia dini memiliki banyak dampak negatif pada masa depan perempuan, karena pernikahan dini akan membatasi gerak sang perempuan, membuat mereka tak punya kesempatan melakukan berbagai hal yang seharusnya mereka lakukan pada usia tersebut (Kurniawan and Yusuf 2021). Bahwa pendapat lain bahwa pernikahan yang berlangsung pada usia dini umumnya akan menimbulkan masalah baik secara fisiologis, psikologis maupun sosial ekonomi. Dampak dan resiko yang timbul akibat pernikahan dini pada umumnya lebih banyak dialami oleh perempuan. Diantaranya dari aspek kesehatan yaitu terjadinya infeksi pada kandungan, penyakit menular seksual, kanker mulut rahim, keguguran dan masalah kesehatan reproduksi lainnya, hal ini dikarenakan organ reproduksi perempuan belum siap menerima kehamilan sehingga dapat menimbulkan berbagai komplikasi. Perempuan muda yang sedang hamil, berdasarkan penelitian akan mengalami beberapa hal, seperti akan mengalami pendarahan, keguguran, dan persalinan yang lama atau sulit (Juliawati et al. 2021).

Dampak negatif dari pernikahan dini lainya yaitu usia yang tengah mencari jati diri sehingga dalam segi mental pun belum siap serta masa remaja membutuhkan pergaulan dan teman sebaya maka hal ini kehilangan kesempatan, begitupun dengan putusnya sekolah maka wanita yang kurang pendidikan dan tidak siap menjalankan perannya sebagai ibu (Kementerian Kesehatan Republik Indonesia 2017). Dampak lainnya dari perkawinan dini yang terjadi pada suami- isteri adalah tidak bisa memenuhi atau tidak mengetahui hak dan kewajiban, hal ini terjadi karena mental mereka yang masih memiliki sifat keegoisan yang tinggi sehingga menyebabkan pertengkaran ,percecokkan, bentrokan antar suami isteri yang dapat mengakibatkan perceraian. Serta dampak apabila pernikahan gagal, maka mereka akan merasa sedih dan kecewa sehingga dari kegagalan tersebut mengakibatkan putusnya hubungan silahturahmi antar keluarga (Tampubolon 2021).

\section{Kepuasan Pernikahan Pasangan Usia Dini}

Kepuasan pernikahan diartikan sebagai bentuk perasaan bahagia dan puas pada kedua pasanganterhadap pernikahan yang dijalaninya yang berkaitan dengan kualitas hubunganyang dijalani dan pengaturan waktu pada pasangan serta bagaimana pasangandapat manajemen keuangan dalam rumah tangganya Dowlatabadi, Saadat, \& Jahangiri (2013). Secara umum, tingkat kepuasan pernikahan gambaran tingkat kebahagiaan dengan pasangan mengenai perasaan tentang pernikahannya ataupun perpektif dan persepsinya tentang pernikahan (Canel 2013). Pengertian lainnya yaitu kepuasan pernikahan merupakan kondisi mental yang menggambarkan manfaat yang dirasakan dengan pasangan hidupnya (Dabone \& Tawiah, 2014; (Kasapoğlu and Yabanigül 2018).

Stone \& Shackelford (2006) mendefinisikan kepuasan pernikahan sebagai keadaan mental yang mencerminkan manfaat dan biaya yang dirasakan seseorang. Kepuasan pernikahan merupakan evaluasi global terhadap keadaan pernikahan seseorang ataupun cerminan kebahagiaan dalam pernikahan (Schoen et al. 2014). Berdasarkan beberapa penjelasan tentang kepuasan pernikahan yang telah dikemukakan di atas, dapat disimpulkan bahwa kepuasan pernikahan pasangan usia dini merupakan gambaran, kondisi mental dan 
perasaan positif mengenai kebahagiaan, rasa puas dan perasaan yang menyenangkan karena terpenuhinya keinginan dan tujuan dalam pernikahan yang dijalani oleh pasangan usia dini.

\section{Terapi Naratif}

Terapi naratif adalah bentuk psikoterapi yang didirikan oleh Michael White dan David Epstonpada 1980-an untuk membantu individu melampirkan makna dan pengalaman hidup (Burgin and Gibbons 2016). Terapi naratif ini yaitu pendekatan yang berfokus pada penulisan ulang atau menceritakan kembali cerita menggunakan teknik eksternalisasi, mencari hasil unik dan mengeksplorasi cerita yang disampai klien kearah perubahan yang lebih baik dengan menggunakan metode kreatif (Sharf 2012). Konselor bekerja sama dengan klien untuk menulis ulang cerita dalam hubungan terapeutik yang kolaboratif, terbuka, dan jujur. Pada akhirnya, konselor yang menggunakan terapi naratif mengambil sikap aktif untuk kesetaraan sosial dan bukan netralitas, sehingga membantu klien merasa lebih didukung dan diterima (Combs and Freedman 2012).

Terapi naratif memungkinkan klien untuk memimpin proses bercerita di mana dia adalah karakter utama dan aspek penting dari hidupnya (Douge 2010). Terapi naratif juga dikenal sebagai bentuk psikososial dari intervensi terapeutik yang digunakan dengan individu, keluarga, kelompok atau organisasi yang semua terapi melibatkan bercerita (Vega et al. 2014). Fungsi dan peran konselor pada pendekatan terapi naratif yaitu sebagai fasilitator aktif yang memiliki kepedulian, minat, rasa ingin tahu dengan penuh hormat, memiliki sikap keterbukaan, empati, dan daya tarik yang tinggi terhadap permasalahan klien (Corey 2017)

Tujuan terapi naratif adalah membantu klien agar dapat membebaskan diri dari permasalahan yang dirasakan dengan cara mengundang klien untuk menyadari bagaimana mereka berhubungan dengan orang lain dalam kehidupan sehari-hari (Feltham, Hanley, and Winter 2017). Lebih lanjut, dalam pelaksanaan terapi naratif ini, konselor berupaya untuk mendengarkan cerita klien terkait masalah yang dirasakan dan memberikan bukti bahwa klien memiliki kompetensi untuk mengambil sikap ataupun tindakan baru (Corey 2017) dan berupaya untuk mengeliminasi masalah klien secepat mungkin atau konselor menggunakan narative reasoning (pertimbangan atau penalaran naratif) yang ditandai dengan cerita dan kebermaknaan, dalam upaya membantu klien mendefinisikan kembali kehidupannya melalui naratif baru (Yusuf 2016).

Pendekatan terapi naratif menekankan pengembangan cerita/kisah alternatif kehidupan klien, dengan harapan bahwa dia dapat menemukan pilihan dan strategi baru untuk menjalani kehidupannya. Agar upaya itu berhasil, maka teknik konseling yang digunakan adalah sebagai berikut. (Corey 2017).

Mengajukan Pertanyaan (Questions and more questions). Pertanyaan sebagai cara untuk menghasilkan pengalaman daripada untuk mengumpulkan informasi. Tujuan bertanya adalah untuk menemukan atau mengkonstruksi mengenai pengalaman klien. Melalui proses mengajukan pertanyaan, klien diberikan kesempatan untuk mengeksplorasi berbagai situasi kehidupan yang menjadi permasalahan klien.

Eksternalisasi dan Dekonstruksi (Externalization and deconstruction). Pada tahap ini, konselor membantu klien mendekonstruksi cerita yang menjadi masalah klien. Ketika klien memandang dirinya sebagai bagian dari masalah, maka dia mengalami keterbiasaan dalam menemukan cara yang dapat mengatasi masalah tersebut secara efektif.

Mencari Hasil Unik (Search for unique outcomes). Pada tahap ini, konselor membicarakan pilihan keberhasilan mengenai masalah yang dihadapi klien. Pertanyaan-pertanyaan tersebut tidak ditanyakan dengan cara rentetan. Bertanya adalah bagian integral dari konteks percakapan naratif yang selaras dengan tanggapan sesuai pertanyaan sebelumnya.

Cerita alternatif dan penulisan ulang (Alternative stories and reauthoring). Pada tahap ini, konselor meminta klien menuliskan segala permasalahan klien. Konselor membantu klien untuk mengingat, memunculkan kembali serta menemukan kisah hidup klien yang leboh bermakna. Pada tahap ini, konselor berupaya agar klien fokus ke masa depan, melalui berbagai pertanyaan hingga klien dapat merenungkan apa yang dimiliki saat ini dan apa langkah selanjutnya.

Mendokumentasikan bukti (Dokumenting the evidence). Pada tahap ini, konselor membantu pengembangan penulisan surat. Surat tersebut berisikan tentang kekuatan dan kemampuan klien yang dapat dibaca pada waktu yang berbeda ataupun lambang perjuangan klien menghadapi permasalahan dan cerita baru tentang pilihan hidupnya. 
Implikasi narrative therapy berbasis nilai-nilai bundo kanduang untuk meningkatkan kepuasan pernikahan pasangan usia dini

Kepuasan pernikahan pada dasarnya merupakan lambang kebahagiaan dalam suatu hubungan pasangan suami-istri dalam rumah tangga. Dimana ketika mengalami permasalahan setiap pasangan memiliki cara yang efektif dalam bersikap, saling menghargai, empati dengan apa yang dirasakan oleh pasangan, saling memberi dukungan, menjalin komunikasi terbuka dan luwes, dan menumbuhkan saling keterbukaan dengan segala aktivitas yang dijalankan. Namun hal ini terkadang yang menjadi persoalan beberapa pasangan usia dini. Pernikahan pasangan di usia muda menjadi sebuah tred di zaman sekarang diberbagai daerah perdesaan yang rentang berakhir dengan perpisahan yang disebabkan oleh berbagai konflik dalam rumah tangga (Mokoginta 2014). Pasangan suami- isteri pernikahan usia dini rentan belum mampu untuk memenuhi serta mengetahui hak dan kewajiban, hal ini terjadi karena mental mereka yang masih memiliki sifat keegoisan yang tinggi sehingga menyebabkan pertengkaran, percecokkan, bentrokan antar suami isteri yang dapat mengakibatkan perceraian (Tampubolon 2021).Menikah diusia yang sangat muda cenderung kurang memiliki pengetahuan serta keyakinan yang tinggi akan masa depan mereka sendiri serta rentan mengalami ketidakstabilan pernikahan yang disebabkan sedikitnya pengalaman mengenai tanggung jawab individu dalam pernikahan (Lehrer 2008), kondisi tersebut tentu dapat memicu ketidakpuasan pernikahan (Mokoginta 2014).

Tingkat kepuasan pernikahan pasangan usia dini rata-rata tergolong rendah (Haryanto et al. 2021) tindakan yang dapat dilakukan untuk menghadari persoalan ketidakpuasan pernikahan usia dini yaitu pengaplikasi terapi naratif. Terapi naratif merupakan teknik konstruksionis sosial dan postmodern terapi keluarga yang bertujuan dapat membantu individu mengevaluasi ulang kisah-kisah hidup mereka dalam pembicaraan (Evans, Turner, and Trotter 2012). Terapi naratif dapat berdampak positif pada kepuasan pernikahan, dalam terapi naratif orang dipandang sebagai ahli utama dalam kehidupan mereka, masalah dieksternalisasi dan efeknya diselesaikan dengan keterampilan, keyakinan, nilai, dan kemampuan mereka sendiri (Ghavibazou et al. 2020).

Terapi naratif membantu pasangan untuk mengatasi masalah mereka dengan mengungkapkan kisah hidup mereka, memberi tahu mereka tentang permasalahan eksternal dari masalah mereka dan berfokus pada hasil yang unik, dekonstruksi cerita sebelumnya, dan menciptakan narasi baru (Abels and Abels 2001; White and Epston 1990). Lebih lanjut terapi naratif membantu konselor dan klien untuk memahami kisah hidup dan merekonstruksinya (Abels and Abels 2001);(Payne 2006) serta efektif untuk berbagai masalah kesehatan mental seperti salah satunya konflik perkawinan. Terapi naratif menyarankan klien dapat menulis ulang ceritanya dan mengakui bahwa perjalanan adalah yang penting, bukan produk atau hasil. Teori ini mempertahankan kesadaran akan keterampilan dan kemampuan individu untuk memungkinkan dia mengenali ceritanya melalui menceritakan kembali dan mengembangkan makna baru. Terapi naratif memberikan kesedihan identitasnya sendiri dan mewujudkannya dengan masa lalu, sekarang, dan masa depan, memungkinkan klien untuk melihat kesedihan mereka secara eksternal, meningkatkan kejelasan perasaan mereka (Peri et al. 2016).

Terapi naratif memandang bahwa setiap manusia dapat memperoleh makna hidupnya sendiri dari berbagai pengalaman yang berkaitan dengan konteks sosial, budaya, dan politik (Ghavibazou et al. 2020). Terapi naratif secara aktif dan sensitif menyesuaikan praktik dengan mempertimbangkan perbedaan lintas budaya atau konselor yang menerapkan terapi naratif harus memodifikasi dan bahkan terkadang menciptakan bentuk narasi sesuai budaya kliennya (Hutto and Gallagher 2017) atau selama proses terapi naratif, klien diarahkan dapat mengeksplorasikan masalahnya sesuai dengan nilai-nilai klien (Ricks et al. 2014), selain itu tujuan terapi naratif yaitu menciptakan kogruen dan cerita yang yang berkaitan dengan budaya dan lingkungan sosial klien (Farrell and Gibbons 2019). Maka dapat disimpulkan bahwa penerapan terapi naratif berdasarkan unsur-unsur budaya klien.

Konselor dalam pemberian layanan konseling perlu memahami perilaku klien sebagai upaya menjembatani permasalahan silang budaya dalam layanan yang diberikannya. Kondisi ini didasari oleh kebudayaan pada suatu masyarakat merupakan perwujudan kemaknaan klien dalam masyarakat itu sendiri. Setiap klien dalam suatu masyarakat dengan latar budaya berbeda memandang permasalahan yang mereka alami secara unik. Pemahaman konstruksi sosial yang telah lama dibangun oleh klien dari masyarakatnya perlu dipahami oleh konselor secara mendasar. Sehingga untuk mewujudkan kehidupan efektif sehari-hari klien perlu strategi pelayanan konseling berbasis budaya (Firman 2018). Budaya Minangkabau yakni mengandung system matrilineal atau garis keturunan ibu, adapun nilai yang harus dimiliki yaitu (1) berani pada kebenaran, (2) jujur dalam bertindak, (3) cerdik dalam kehidupan, (4) pemurah dan pemahal, dan (5) penyabar dan ridho (Syaputra et al. 2019).

Adapun pelaksanaannya terapi naratif dilaksanakan dalam lima sesi: (1) mengajukan pertanyaan: mempelajari masalah secara mendalam dan komprehensif tentang kepuasan pernikahan, preferensi bahasa 
klien, preferensi mendengarkan sebelum bertanya tentang masalah pasangan usia dini dengan nilai karakter bundo kanduang yaitu: (a) nilai keberanian, pada tahap ini konselor berupaya memberikan mengajukan pertanyaan terkait dengan kebahagiaan yang dirasakan oleh pasangan usia dini. Dalam hal ini konselor memberikan penghargaan di setiap informasi yang diberikan klien, (b) kebenaran, pada tahap ini, konselor mengupayakan agar klien dapat mengungkapkan segala realita kehidupannya (c) kejujuran, pada tahap ini konselor memberikan penerimaan yang hangat agar klien dapat menyampaikan segala yang dirasakan (e) keoptimisan, pada tahap ini konselor berupaya memberikan motivasi yang tinggi akan pernikahan yang telah dijalankan (f) ketakwaan, pada tahapp ini, konselor mengarahkan klien agar lebih mendekatkan diri kepada Allah SWT, (g) kemandirian, pada tahap ini konselor berupaya mengarahkan klien agar sabar akan niat baik sebelum menikah dan, (h) nilai tanggungjawab, pada tahap ini, konselor berupaya agar klien fokus ke masa depan, melalui berbagai pertanyaan hingga klien dapat merenungkan apa yang dimiliki saat ini dan apa langkah selanjutnya serta tanggung jawab yang harus dimiliki. Lebih lanjut, segala cerita yang diungkapkan oleh klien di dokumentasikan agar dapat dibaca dikemudian hari oleh pasangan usia muda.

\section{Simpulan}

Setiap pasangan yang menikah pasti mendambakan kebahagiaan dan kepuasan dalam pernikahan. Adapun salah satu yang dapat dilakukan yaitu melalui proses konseling, pada proses konseling untuk mewujudkan kehidupan efektif sehari-hari perlu strategi pelayanan konseling berbasis budaya. Terapi naratif merupakan salah satu teknik konseling yang dapat meningkatkan kepuasan pernikahan. Dalam penelitian ini, terapi naratif memberikan kesempatan bagi pasangan usia dini untuk mengeksternalisasi masalah daripada menyalahkan diri sendiri dan/atau pasangannya atas ketidakpuasan mereka dan mencoba memecahkan masalah dengan solusi terbaik. Ini membantu orang menceritakan narasi mereka sambil memahami diri mereka sendiri dan kebutuhan pasangan mereka dan untuk belajar tentang harapan satu sama lain.

\section{Referensi}

Abels, Paul, and Sonia L. Abels. 2001. Understanding Narrative Therapy (A Guidebook for the Social Worker). Bill Tucke. edited by J. W. Libby. New York.

Asak, Ni Luh Ari Pradnyadewi, and Ni Made Ari Wilani. 2019. "Peran Kecerdasan Emosi Terhadap Kepuasan Pernikahan Pada Remaja Yang Menikah Muda Di Bali." Jurnal Psikologi Udayana 6(02):337. doi: 10.24843/jpu.2019.v06.i02.p13.

Burgin, Emma C., and Melinda M. Gibbons. 2016. "'More Life, Not Less': Using Narrative Therapy with Older Adults with Bipolar Disorder." Adultspan Journal 15(1):49-61. doi: 10.1002/adsp.12019.

Canel, Azize Nilgün. 2013. "The Development of the Marital Satisfaction Scale (MSS)*." Educational Sciences: Theory \& Practice 13(1):97-117.

Combs, Gene, and Jill Freedman. 2012. "Narrative, Poststructuralism, and Social Justice : Current Practices in Narrative Therapy." The Counseling Psychologist 40(7):1033-60. doi: $10.1177 / 0011000012460662$.

Corey, Gerald. 2017. Theory and Practice of Counseling and Psychotheraphy, Eighth Edition. USA.

Dabone, and Kyeremeh Tawiah. 2014. "Effects of Age on Marital Satisfaction of Married People in Sunyani Municipality." International Journal of Research In Social Sciences 3(8):48-57.

Douge, Jenny. 2010. "Scrapbooking: An Application of Narrative Therapy." Procedia - Social and Behavioral Sciences 5:684-87. doi: 10.1016/j.sbspro.2010.07.165.

Dowlatabadi, Fatemeh Hosseini, Sajjad Saadat, and Sobhan Jahangiri. 2013. "The Relationship between Religious Attitudes and Marital Satisfaction among Married Personnel of Departments of Education in Rasht City , Iran." International Journal of Advanced Studies in Humanities and Social Science 1(6):608-15.

Dwinanda, Aditya Risky, Anisa Catur Wijayanti, and Kusuma Estu Werdani. 2017. "Hubungan Antara Pendidikan Ibu Dan Pengetahuan Responden Dengan Pernikahan Usia Dini." Jurnal Kesehatan Masyarakat Andalas 10(1):76. doi: 10.24893/jkma.v10i1.166.

Evans, Philipa, Shelley Turner, and Chris Trotter. 2012. "The Effectiveness of Family and Relationship Therapy. A Review of the Literature." (October):37.

Farrell, Isabel C., and Melinda M. Gibbons. 2019. "Using Narrative Therapy to Assist College-Age Latino Immigrants." Journal of College Counseling 22(1):83-96. doi: 10.1002/jocc.12116.

Feltham, Colin, Terry Hanley, and Laura Anne Winter. 2017. The Sage Handbook of Counselling and Psychotherapy. Los Angeles/London/New Delhi/Singapore/Washinton DC/Melbourne: SAGE Publications Ltd.

Firman, Firman. 2018. "Kekuatan Kompetensi Budaya Konselor Dalam Layanan Konseling Multikultural Terhadap Masyarakat Asean." (October). doi: 10.31227/osf.io/j9xps. 
Ghavibazou, Effat, Simin Hosseinian, and Abbas Abdollahi. 2020. "Effectiveness of Narrative Therapy on Communication Patterns for Women Experiencing Low Marital Satisfaction." Australian and New Zealand Journal of Family Therapy 41(2):195-207. doi: 10.1002/anzf.1405.

Haryanto, Sri, Andini Restu Marsiwi, Evi Nurnaini, and Syahrani Widya Meifani. 2021. "Korelasi Karakteristik Responden Dengan Kepuasan Pernikahan Pada Istri Yang Melakukan Pernikahan Dini Di Kecamatan Pegedangan." Edu Dharma Journal 5(1):9-22.

Hutto, Daniel D., and Shaun Gallagher. 2017. "Re-Authoring Narrative Therapy: Improving Our Selfmanagement." Philosophy, Psychiatry, \& Psychology 24(2):157-67.

Jannah, Miftahul, Sukri Paluttur, and Muhammad Syafar. 2021. "Determinan Terjadinya Pernikahan Usia Dini Serta Dampaknya Terhdap Keluarga Dan Masyarakat." Jurnal Ilmiah Kesehatan Sandi Husada 10(2):519-26. doi: 10.35816/jiskh.v10i2.641.

Juliawati, Eva Erna, Astrid Novita, and Rita Ayu Yolandia. 2021. "Determinan Pernikahan Usia Dini Pada Remaja." SIMFISIS Jurnal Kebidanan Indonesia 1(2):53-65. doi: 10.53801/sjki.v1i2.20.

Karney, Benjamin R., and Thomas N. Bradbury. 2020. "Research on Marital Satisfaction and Stability in the 2010s: Challenging Conventional Wisdom." Journal of Marriage and Family 82(1):100-116. doi: 10.1111/jomf.12635.

Kasapoğ lu, Figen, and Ayş enur Yabanigül. 2018. "Marital Satisfaction and Life Satisfaction: The Mediating Effect of Spirituality." Spiritual Psychology and Counseling 3(2):177-95. doi: 10.37898/spc.2018.3.2.0048.

Kementerian Kesehatan Republik Indonesia. 2017. PROFIL KESEHATAN INDONESIA Tahun 2016.

Köppen, Katja, Michaela Kreyenfeld, and Heike Trappe. 2018. "Loose Ties? Determinants of Father-Child Contact After Separation in Germany." Journal of Marriage and Family 80(5):1163-75. doi: 10.1111/jomf.12504.

Kurniawan, D., and A. M. Yusuf. 2021. "Hubungan Antara Kontrol Diri Dan Dukungan Sosial Orangtua Dengan Keberhasilan Keluarga Pada Pernikahan Usia Dini Di Kota Padang." Edukatif: Jurnal Ilmu Pendidikan 3(4):1757-64.

Lehrer, Evelyn L. 2008. "Age at Marriage and Marital Instability: Revisiting the Becker-Landes-Michael Hypothesis." Journal of Population Economics 21(2):463-84. doi: 10.1007/s00148-006-0092-9.

Mangande, Jeneri, and John Lahade. 2021. "Kualitas Pernikahan Dan Status Kesehatan Mental Pada Perempuan Yang Menikah Usia Dini 1." Jurnal Keperawatan Jiwa (JKJ): Persatuan Perawat Nasional Indonesia 9(2):293-310.

Mokoginta, Fina. 2014. "Kecerdasan Emosi, Religiusitas Dan Kepuasan Pernikahan Pada Wanita Muslim Yang Menikah Muda." TAZKIYA: Journal of Psychology 2(1):103-15. doi: 10.15408/tazkiya.v2i1.10761.

Payne, Martin. 2006. Narrative Therapy. Vol. 148. Second. edited by I. O. Yard. London: SAGE Publications Ltd.

Peri, Tuvia, Ilanit Hasson-Ohayon, Sharon Garber, Rivka Tuval-Mashiach, and Paul A. Boelen. 2016. "Narrative Reconstruction Therapy for Prolonged Grief Disorder-Rationale and Case Study." European Journal of Psychotraumatology 7(February). doi: 10.3402/ejpt.v7.30687.

Ricks, Lacey, Sarah Kitchens, Tonia Goodrich, and Elizabeth Hancock. 2014. "My Story: The Use of Narrative Therapy in Individual and Group Counseling." Journal of Creativity in Mental Health 9(1):99110. doi: 10.1080/15401383.2013.870947.

Santrock. 2002. Life Span Development. Alih Bahasa: Achmad Chusairi Dan Juda Damanik. Jakarta: Erlangga.

Schoen, Robert, Nan Marie Astone, Kendra Rothert, Nicola J. Standish, and J. Young. 2014. "Women 's Employment , Marital Happiness , and Divorce *." Social Force 81(2):643-62.

Sharf, Richard S. 2012. Theories of Psychotherapy and Counseling. USA: Brooks/Cole, Cengage Learning.

Stone, Emily A., and Todd K. Shackelford. 2006. "Marital Satisfaction." (May).

Syaputra, Yogi Damai, Nur Hidayah, M. Ramli, and Alfaiz Alfaiz. 2019. "Metaanalisis Karakter Integritas Siswa Berbasis Nilai Bundo Kanduang Era Revolusi Industri 4.0." Counsellia: Jurnal Bimbingan Dan Konseling 9(2):165. doi: 10.25273/counsellia.v9i2.5266.

Tampubolon, Elisabeth Putri Lahitani. 2021. "Permasalahan Perkawinan Dini Di Indonesia." Jurnal Indonesia Sosial Sains 2(5):738-46.

Vega, B. Rodríguez, C. Bayón Pérez, A. PalaoTarrero, and A. Fernández Liria. 2014. "Mindfulness-Based Narrative Therapy for Depression in Cancer Patients." Clinical Psychology and Psychotherapy 21(5):411-19. doi: 10.1002/cpp.1847.

White, Michael, and David Epston. 1990. Narrative Means to Therapeutic Ends. Vol. 148. New York: Norton \& Company.

Wowor, Savira. 2020. "Perceraian Akibat Pernikahan Dibawah Umur (Usia Dini)." Jurnal Indonesia Sosial Sains 1(September):132-41.

Yusuf, Syamsu. 2016. Konseling Individual (Konsep Dasar \& Pendekatan). edited by D. Sumayyah. Bandung: PT. RefikaAditama. 